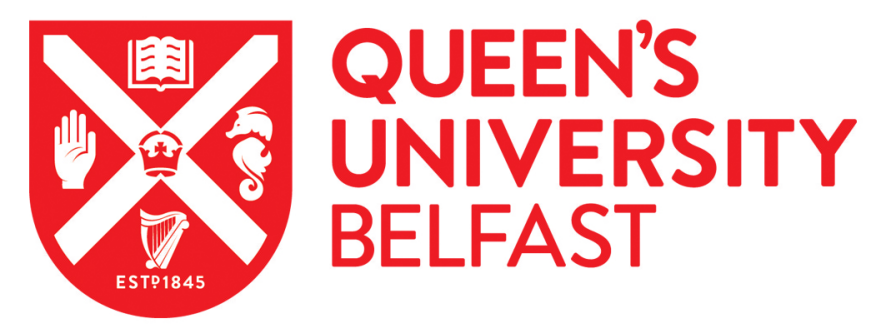

\title{
Multiple Breath Washout (MBW) training, certification and quality control during the iBEST - 1 trial in bronchiectasis (BE).
}

O'Neill, K., Tunney, M., Angyalosi, G., Haworth, C. S., Loebinger, M. R., Bradley, J., \& Elborn, J. (Accepted/In press). Multiple Breath Washout (MBW) training, certification and quality control during the iBEST - 1 trial in bronchiectasis (BE).. 1-2. Abstract from European Respiratory Society International Congress 2018, Paris, France.

Document Version:

Peer reviewed version

Queen's University Belfast - Research Portal:

Link to publication record in Queen's University Belfast Research Portal

Publisher rights

Copyright CERS 2018. This work is made available online in accordance with the publisher's policies. Please refer to any applicable terms of use of the publisher.

\section{General rights}

Copyright for the publications made accessible via the Queen's University Belfast Research Portal is retained by the author(s) and / or other copyright owners and it is a condition of accessing these publications that users recognise and abide by the legal requirements associated with these rights.

Take down policy

The Research Portal is Queen's institutional repository that provides access to Queen's research output. Every effort has been made to ensure that content in the Research Portal does not infringe any person's rights, or applicable UK laws. If you discover content in the Research Portal that you believe breaches copyright or violates any law, please contact openaccess@qub.ac.uk. 


\section{Multiple Breath Washout (MBW) training, certification and quality control during the iBEST- 1 trial in bronchiectasis (BE).}

Bronchiectasis, Lung function testing
K. O'Neill ${ }^{1}$, M.
M. M. Tunney ${ }^{2}$,
G. Angyalosi $i^{3}$
C. Haworth ${ }^{4}, M$ Stuart Elborn ${ }^{7}$

${ }^{1}$ Wellcome-Wolfson Institute for Experimental Medicine, Queen's University - Belfast (United Kingdom), ${ }^{2}$ School of Pharmacy, Queen's University - Belfast (United Kingdom), ${ }^{3}$ Novartis Pharma AG - Basel (Switzerland), ${ }^{4}$ Cambridge Centre for Lung Infection, Papworth Hospital - Cambridge (United Kingdom), ${ }^{5}$ Host Defence Unit, Royal Brompton Hospital, Imperial College London, - London (United Kingdom), ${ }^{6}$ Wellcome-Wolfson Institute for Experimental Medicine, Clinical Research Facility - Belfast (United Kingdom), ${ }^{7}$ Wellcome-Wolfson Institute for Experimental Medicine, Queen's University Belfast; Host Defence Unit, Royal Brompton Hospital, Imperial College London - London (United Kingdom)

Background: Lung clearance index $(\mathrm{LCl})$ measured by MBW, is an exploratory endpoint in iBEST-1. MBW set up requires staff training, certification and central "over-reading" for data quality control. Evaluation of these processes is essential to inform the inclusion of $\mathrm{LCl}$ in future BE studies.

Objectives: To summarise the time duration between MBW training \& certification and the proportion of tests excluded after over-reading. Methods: Twenty-seven sites are participating in the LCl sub-study. MBW training was a 1 day face to face session, eLearning tool and mentoring support. Certification required the submission of $8 / 10$ valid tests. Once certified, sites submitted trial MBW data for assessment by a trained "over-reader" using pre-defined criteria (Jensen et al. 2016, PLOS ONE).

Results: Training: $20 / 27$ sites completed training. Six had previously completed training \& certification. One site was unable to participate (language barrier). Of the 20 sites that completed training, 12/20 (60\%) were MBW naive. 13/20 (65\%) completed certification with a mean (range) time since training of 6 (4-14) months. Certification for $6 / 20$ sites is on-going with a mean (range) time since training of 10 (3-17) months. One site dropped out (no equipment space). Over-reading: To date, 146 tests from 10 sites have been submitted. $52 / 146(36 \%)$ tests were excluded, most commonly due to leak, irregular breathing pattern and technical issues. 
Conclusions: Sites require a mean of 6 months to train and certify in MBW testing for BE trials. The study is on-going to determine the support necessary to minimise test exclusion.

Support received from EU/EFPIA IMI-JU iABC grant $\mathrm{n}^{\circ} 115721$. 